\title{
Bir Ermeni Köyü Olan Adiş'in Siyasî, Sosyal, Ekonomik ve Dinî Durumu
}

\author{
Oktay Bozan*
}

(ORCID: 0000-0003-0485-556X)

Makale Gönderim Tarihi

26.04.2021
Makale Kabul Tarihi

25.09.2021

\section{Atıf Bilgisi/Reference Information}

Chicago: Bozan, O., "Bir Ermeni Köyü Olan Adiş'in Siyasî, Sosyal, Ekonomik ve Dinî Durumu", Vakanüvis-Uluslararası Tarih Araştırmaları Dergisi, 6/2 (2021): 511-536.

APA: Bozan, O. (2021). Bir Ermeni Köyü Olan Adiş'in Siyasî, Sosyal, Ekonomik ve Dinî Durumu. Vakanüvis-Uluslararası Tarih Araştırmaları Dergisi, 6 (2) , 511536.

\section{Öz}

Adiş, Diyarbakır vilayetinin Çüngüş kazasına bağlı bir köydür. Çüngüş, Müslümanlar ve gayrimüslimlerin yaşadığı bir yerleşim merkezidir. 1516 yılında Osmanlı idaresine girdikten sonra yapılan idari düzenleye göre Çüngüş'e bağlı köylerden sadece Adiş̧'ta Ermeniler yaşamaktadır. Adiş, Osmanlı kayıtlarının büyük bir kısmında Adiş-i Süflâ (Aşağı Adiş) ve Adiş-i Ulyâ (Yukarı Adiş) şeklinde geçmekle birlikte bir kısmında ise sadece Adiş olarak tanımlanmıştır. XVI ve XVII. yüzyıl kayıtlarına göre Adiş köyünde sadece Ermeniler yaşarken XIX. yüzyılın başından itibaren Müslümanlar da Adiş köyüne yerleşmiştir. Adiş köyü, yetersiz tarım alanlarına sahip olması nedeniyle köyün erkeklerinin önemli bir kısmı İstanbul'a giderek ailesinin ihtiyaçlarıı temin etmek zorunda kalmıştır. XIX. yüzyııın sonlarında 300 haneye ulaşan köyde eğitim kurumları ve kiliseler bulunmaktadır. 1895 Ermeni olayları sırasında Gerger tarafından gelen eşkıya, Adiş köyüne saldırılarda bulunmuş ve birtakım mağduriyetler yaşanmıştır.

\footnotetext{
* Doçent Doktor, Dicle Üniversitesi Edebiyat Fakültesi Tarih Bölümü, Türkiye, oktaybozan210@gmail.com.

Assoc. Prof. Dr., Dicle University Faculty of Arts and Sciences, Department of History, Turkey.
}

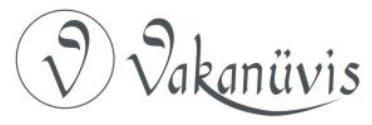


Anahtar Kelimeler: Çüngüş, Adiş Köyü, Değirmensuyu Köyü, Ermeniler, 1895 Ermeni Olayları.

\title{
The Political, Social, Economic and Religious Status of Adish, An Armenian Village
}

\begin{abstract}
Adish i a village in the Chungush district of Diarbekir province. Chungush is a residential center where Muslims and non-Muslims live. According to the administrative regulation made after the Ottoman rule in 1516, Adish is the only village where Armenians live among the villages of Chungush. Although Adiş is mentioned as Adiş-i Süflâ (Lower Adiş) and Adiş-i Ulyâ (Upper Adiş) in most of the Ottoman records, it was defined as Adish only in some records. According to the records of the 16th and 17th centuries only Armenians lived in Adiş, since the beginning of the 19th century, Muslims have also settled in the village of Adiş. Since Adish village has insufficient agricultural areas, a significant portion of the men of the village had to go to Istanbul to meet the needs of their family. There were educational institutions and churches in the village, which reached 300 households at the end of the 19th century. During the Armenian events of 1895, the bandit which came from Gerger attacked the village of Adish and some grievances were experienced.
\end{abstract}

Keywords: Chungush, Adish Village, Değirmensuyu Village, Armenians, 1895 Armenian Events.

\section{Giriş}

Çüngüş, tarih boyunca birçok devletin ele geçirmek için mücadele ettiği, Fırat ve Dicle nehirleri arasında kalan Mezopotamya toprakları üzerinde yer almaktadır. Dağlık arazi ve Fırat Nehri'nin çok derin bir yatağıyla batıda Adıyaman ve Malatya'dan ayrılan Çüngüş, kuzeyde Harput ve güneydoğuda Diyarbakır'a hâkim olan devletlerin idaresinde kalmıştır. Çüngüş, sahip olduğu doğal koruma nedeniyle eski bir yerleşim merkezidir. Ancak Çüngüş yöresinin dağıı olması, verimli topraklarının bulunmaması ve ulaşım zorluğu gibi nedenlerle yoğun bir yerleşim alanı olmamıştır ${ }^{1}$. Çüngüş, Osmanlı idaresine girdiğinde şehir

\footnotetext{
${ }^{1}$ Fahrettin Kırzıoğlu, "Çermik Kasabası Üzerine Notlar", Kara Amid Dergisi, S.1, İstanbul, 1856, s. 279.
}

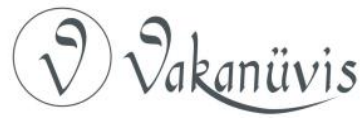


merkezinde Müslümanlar ve gayrimüslimler yaşamakta idi. O dönemde Çüngüş kazası, Türk, Zaza ve Ermeni yerleşim birimidir. Ancak Çüngüş merkezindeki Müslümanlar XX. yüzyılın sonlarına kadar tamamen Türklerden oluşmaktaydıํ. Türklerin Çüngüş'teki varlığını, Anadolu'ya akınlarla gelen Türklerin iskanına kadar götürmek mümkündür ${ }^{3}$.

Osmanlı idaresinde girdikten kısa bir süre sonra yapılan 1518 tarihli tahrirde kasaba merkezindeki 27 hane, 2 mücerred Müslüman; 116 hane ve 13 mücerred gayrimüslim vardır. 1530 tarihli tahrirde 58 hane, 23 mücerred, 4 muaf Müslüman ile 192 hane ve 81 mücerred gayrimüslimdir. 1566 tarihli tahrirde ise 129 hane ve 31 mücerred Müslüman, 406 hane ve 126 mücerred gayrimüslim vergi mükellefi yaşamakta idi ${ }^{4}$. Bu tahrir kayıtları dikkate alındığında Çüngüş merkezindeki nüfusun yaklaşık \% 70'inin gayrimüslim olduğu görülmektedir. Dolayısı ile Çüngüş, Müslümanlardan ziyade gayrimüslimlerin (Ermenilerin) yoğun olduğu bir yerleşim merkezidir. Bu nedenle Ermenilerin, Müslümanlardan önce şehrin sakini olduğu kanaatindeyiz. Bu çalışmada Osmanlı Devleti döneminde Çüngüş kazasına/nahiyesine bağıı bir Ermeni köyü olan Adiş'ın (şimdiki adıyla Değirmensuyu) siyasî, sosyal, ekonomik ve dinî durumu tespit edilmeye ve değerlendirilmeye çalışılmıştır.

\section{Adiş Köyünün Sakinleri ve Nüfusu}

Harput, 1516 yılında Osmanlı hâkimiyetine girdikten sonra sancak olarak Diyarbakır Eyaleti'ne bağlanmıştı ${ }^{5}$. Kemah emiri Karaçin oğlu Ahmet Bey, Mirdasi beyleriyle Çermik'i fethetmiştir. Sakinleri hiç mukavemet etmeden teslim olmuş ve haber Yavuz Sultan Selim'e 15 Aralık 1516'da ulaşmıştır'. Bu durum dikkate alındığında Çüngüş'ün 1516 yılında Osmanlı Devleti'nin idaresi altına girdiği kuvvetle

2 Mustafa Öztürk-ibrahim Yılmazçelik, “Arifî Paşa'nın Seyahatnamesi Diyarbekir Seyahati”, Belgeler, Türk Tarih Kurumu, Cilt: 18, Sayı: 22, Yıl: 1997, s. 108.

${ }^{3}$ Osman Turan, Selçuklular Tarihi ve Türk-Islam Medeniyeti, Ötüken Yayınları, İstanbul, 1980, s. 204.

${ }^{4}$ Mehmet Salih Erpolat, “XVI. Yüzyılda Ergani Sancağı'ndaki Gayrimüslim İskân Yerleri ile Şahıs İsimleri Hakkında Bir Değerlendirme”, Sosyal Bilimler Araştırma Dergisi, Yıl: 2, Sayı: 4, Diyarbakır, 2004, s.162.

${ }^{5}$ Mehdi IIlhan, Amid (Diyarbakır) 1518 Tarihli Defter-i Mufassal, TTK, Ankara, 2000, s. 84.

${ }^{6}$ Feridun, Münşeatü's-Selatin, İstanbul, 1274, İstanbul, C.I, s. 396.

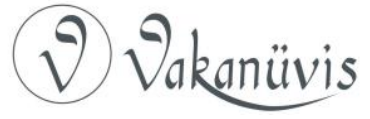


muhtemeldir7. 1518, 1530 ve 1566 tarihli tahrir kayıtlarında Çüngüş nahiyesine bağı köylerden sadece bir tanesinde Ermeniler sakindir. Bununla birlikte Çüngüş'e bağlı Karakilise, Kilise Tahtamaşat, Ermiye, Ağut, Arguna ve Elyos gibi yerleşim biriminin isminin Ermenice olduğu iddia edilse de bu köylerde Ermenilerin yaşadığına dair herhangi bir kayıt söz konusu değildir. Çüngüş ile ilgili tahrir, nüfus ve kefalet defterinin hiçbirisinde de bu köylerde Ermenilerin yaşadığına dair kayıt veya ima söz konusu değildir. Kanaatimizce Osmanlı Devleti öncesinde söz konusu köylerin bir kısmında (Karakilise, Kilise Tahtamaşat) Ermeniler veya diğer Hıristiyan mezheplerine mensup kişiler yaşamaktaydı. Bu nedenle onlara ait kilise ve mezarlıklar ile köy isimleri sonraki dönemde bölgeye yerleşen Müslümanlar tarafından kullanılmış ve sözlü kültür olarak aktarılmıştır.

Adiş isminin ne anlama geldiği hakkında herhangi bir kayda rastlamadık. Ancak kanaatimizce Adiş ismi, köyün ilk sakinlerinden birisinin adı olmalıdır. Osmanlı kayıtlarında Adiş (Adış), bazen Aşağı Adiş (Adiş-i Süflâ) ve Yukarı Adiş (Adiş-i Ulyâ) şeklinde, bazen de sadece Adiş olarak geçmektedir. 1518 tarihli Diyarbekir Vilayeti 64 numaralı Tahrir Defteri'nde Adiş-i Süflâ'da 15, Adiş-i Ulyâ'da ise 23 gayrimüslim vergi mükellefinin ismi yer almaktadır .

\footnotetext{
7 Abdülgani Bulduk, El-Cezîre'nin Muhtasar Tarihi, Yay. Haz: Mustafa Öztürk-ibrahim Yılmazçelik, Fırat Üniversitesi Orta Doğu Araştırmaları Merkezi Yayınları, Elazığ, 2004, s. 104.

${ }^{8}$ Mehmet Salih Erpolat, “XVI. Yüzyılda Ergani Sancağı'ndaki Gayrimüslim İskân Yerleri ile Şahıs İsimleri Hakkında Bir Değerlendirme", Sosyal Bilimler Araştırma Dergisi, Yıl: 2, Sayı: 4, Diyarbakır, 2004, s.176-178.
}

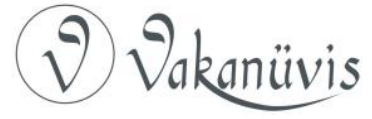




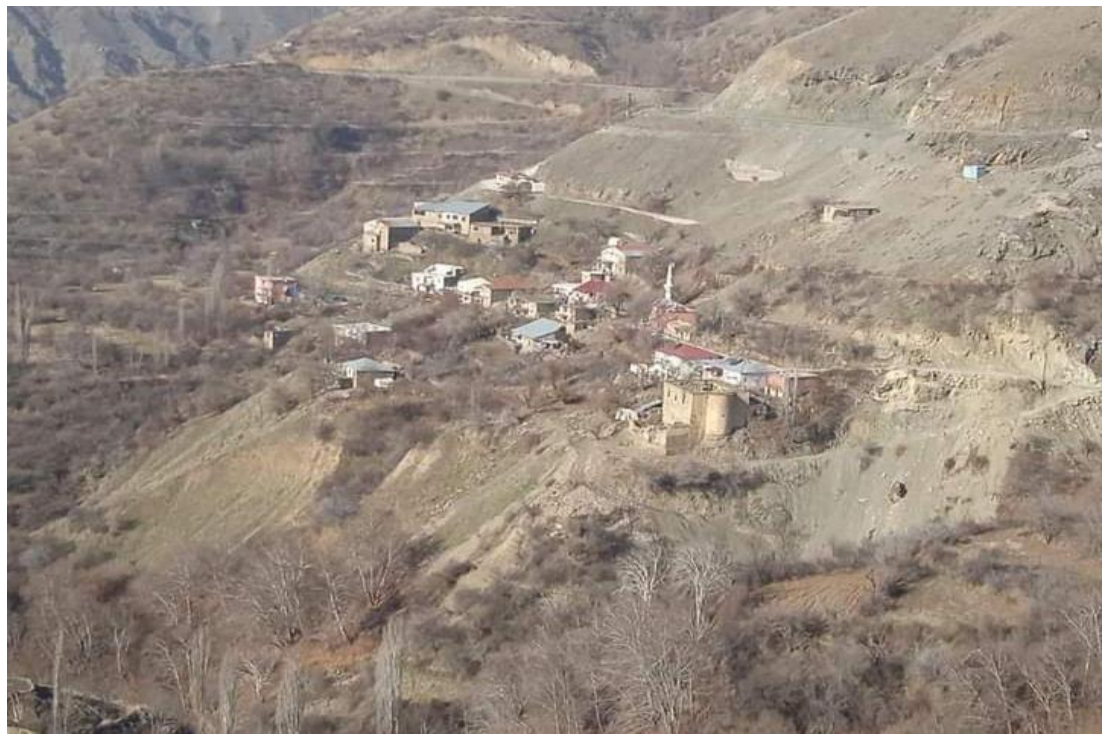

(Adiş/Değirmensuyu Köyü)

XVI. yüzyılda yapılmış olan tahrirlere göre Adiş köyünde sadece Ermeniler yaşamaktadır. Diyarbekir Eyaleti'nin 3409 numaralı ve 1691 tarihli Cizye Defteri'nde Adiş-i Ulyâ ve Adiş-i Süflâ köylerinde 51 cizye mükellefi kişi bulunmaktadır ${ }^{9}$. Çüngüş Ermenileri hakkında bilgi veren H.1106/M.1694-95 tarihli cizye defterinde ise Adiş-i Ulyâ köyünde 74, Adiş-i Süflâ köyünde ise 108 vergi mükellefi vardır ${ }^{10} .3409$ numaralı cizye defteri ile 3640 numaralı defterin düzenlenme tarihleri arasında 3-4 yıl bulunmaktadır. Ancak vergi mükellefi kişileri dikkate aldığımızda arada büyük bir fark vardır. Zira 3409 numaralı defterde 51 cizye mükellefi varken, 3640 numaralı deftere göre ise 182 kişi bulunmaktadır. Bunun nedeninin defterin sağlıklı düzenlenmemesinden kaynaklandığını düşünmekteyiz. Zira 1691 tarihli Cizye Defteri'nde 77 cizye mükellefi kişi, Adiş köyüne yakın olan Elyos (Malkaya) köyü üzerinde gösterilmiştir. Bu nedenle söz konusu bilginin sıhhati tartışmalıdır. Zira Elyos köyü Adiş köyüne çok yakın olmakla birlikte Müslüman ahalinin yaşadığı ve etnik olarak da Türk olan bir yerleşim merkezidir. Osmanlı Devleti idaresine girdikten sonra yapılan 1518, 1530 ve 1566 tarihli

${ }^{9} B O A, M A D . d, 3409$, s. 22-34.

${ }^{10} B O A, M A D . d, 3640$, s. 142-145.

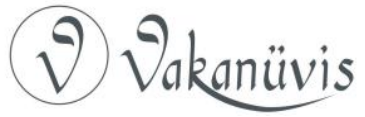


tahrir defterlerinde Elyos köyünde sadece Müslümanların yaşadığı ve hiç gayrimüslim vergi mükellefi olmadığı görülmektedir. Bununla birlikte Çüngüş'e bağlı köylerdeki cizye mükellefi Ermenileri hakkında bilgi veren H.1106/M.1694-95 tarihli Maliyeden Müdevver Defterler (MAD.d.) 3640 nolu defterde de Elyos köyünde hiçbir Ermeni bulunmamaktadır ${ }^{11}$. Ayrıca 1842 tarihli Nüfus Defteri ile 1846 tarihli Kefalet Defteri'nde de Elyos köyünde hiçbir Ermeni yer almamaktadır. 1566 tarihli tahrirde Elyos'da Ermeniler yer almazken yaklaşık 130 yıl sonraki cizye defterinde Elyos'da görünmesi sehven yapılmış bir hata olmalıdır. 1842 tarihli Çüngüş Nüfus Defteri'ne göre Adiş köyündeki Ermenilerin mahalle bazında hane ve kişi sayısı şöyledir ${ }^{12}$ :

\begin{tabular}{|l|l|l|l|}
\hline Sıra & Köy ve Mahalleler & Hane sayısı & $\begin{array}{l}\text { Kişi } \\
\text { sayısı }\end{array}$ \\
\hline 1 & Keşiş Garabid Mahallesi & 43 & 156 \\
\hline 2 & Keşiş Beydiros Mahallesi & 40 & 121 \\
\hline 3 & Keşiş Kiyo Mahallesi & 48 & 156 \\
\hline 4 & Keşiş Mardiros Mahallesi & 41 & 142 \\
\hline \multicolumn{2}{|l|}{ Toplam } & 172 & 575 \\
\hline
\end{tabular}

Bu çizelgeye bakıldığında Adiş Köyü'ne bağlı dört mahalle bulunmaktadır. Bu mahallelerin hepsi de "keşiş" lakaplı din adamlarının adına izafeten oluşturulmuştur. Osmanlı idari teşkilatının en küçük birimi olan köylerde mahalle teşkili pek rastlanılan bir durum değildir. Ancak hem 1842 tarihli nüfus defterinde hem de 1846 tarihli kefalet defterinde Adiş köyünün geçtiği kısımda mahalleler yer almaktadır. 1842 tarihli nüfus defterine göre mahallelerdeki hane sayısı 172, erkek kişi sayısı ise 575'tir. Kadınları da erkekler oranında dikkate aldığımızda yaklaşık 1150 Ermeni'nin Adiş köyünde yaşadığı söylenebilir. Kefalet Defterinde ise Çüngüş'e tabi Adiş köyü verildikten sonra üç mahalle sıralanmıştır. Keşiş unvanlı din adamları adına oluşturulmuş olan mahallelerin Yukarı Adiş'e mi yoksa Aşağı Adiş'e mi bağlı olduğu belirtilmemiştir.

\footnotetext{
${ }^{11}$ BOA, MAD. d, 3640, s. $142-145$

12 BOA, NFS.d., 2662.
}

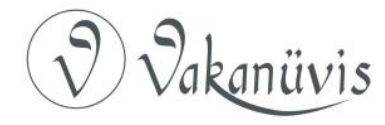


1842 tarihli nüfus sayımından 4 yıl sonra yapılan 1846 tarihli Çüngüş Kefalet Defteri'ndeki kayıtlara göre Adiş köyü ve bağlı mahallelerindeki kişi dağııımı ise şöyledir:

\begin{tabular}{|l|l|l|}
\hline Sıra & Mahalleler & Kişi sayısı \\
\hline 1 & Adiş Köyü & 102 \\
\hline 2 & Keşiş Bedros Mahallesi & 98 \\
\hline 3 & Keşiş Kivork Mahallesi & 119 \\
\hline 4 & Keşiş Mardures Mahallesi & 87 \\
\hline Toplam & 406 \\
\hline
\end{tabular}

Buna göre Adiş köyünde 102 kişi bulunurken geri kalan üç mahallede ise 304 kişi yer almaktadır. Adiş ve bağlı mahallelerde toplam 406 kişinin varlığı, bu köyünün önemli bir nüfusa sahip olduğunu göstermektedir. Zira Çüngüş'e bağlı Müslüman köylerden hiç birisinde bu kadar bir nüfus yoktur. Kefalet kapsamındaki kişi sayısının hanedeki kişi sayısının yaklaşık dörtte biri olduğu düşünüldügünde Adiş köyünde yaklaşık 2000 kişinin olduğu düşünülebilir. $O$ günün koşullarında yoğun bir nüfusa sahip olduğu görülen Adiş'in XVI. yüzyılda, Osmanlı idaresine girdiğinde de yoğun bir nüfusa sahip olduğu tahrir kayıtlarından anlaşılmaktadır. Her ne kadar yukarıdaki çizelgede Adiş köyünün bir kısmı mahalle olarak kaydedilmişse de birçok kaynakta Adiş köyünün mahalle zikredilmeden ifade edilmiştir. Nitekim 1897 tarihli bir vergi çizelgesinde Adiş'in Çüngüş kasabasına bağlı tek Ermeni köyü olduğu görülmektedir ${ }^{13}$. Bu arada Çüngüş nüfus ve kefalet defterlerindeki Adiş köyü ile ilgili kayıtlara bakıldığında birtakım hatalar dikkat çekmektedir. Nüfus Defteri'ndeki Keşiş Bedros, Kefalet Defteri'nde Beydiros şeklinde, Keşiş Kiyo, Keşiş Kivork olarak, Keşiş Mardiros ise Keşiş Mardures olarak ifade edilmiştir. $\mathrm{Bu}$ durumun kâtibin Ermenice isimlere vakıf olmamasından veya özensizliğinden kaynaklandığını düşünmekteyiz. 1842 tarihli Nüfus Defteri'nde Keşiş Garabid adıyla geçen 43 haneli mahalle 1846 tarihli Kefalet Defteri'nde ise Adiş köyü olarak geçmektedir.

XVI. yüzyılda sadece Ermenilerin yaşadığı Adiş köyünde ilerleyen zamanlarda Müslümanların da yerleştiği anlaşılmaktadır. Nitekim 1842

${ }^{13}$ BOA, DH.TMIK.M.. , 145/67, s. 5.

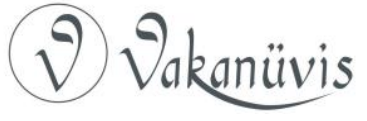


tarihli Çüngüş Nüfus Defteri'nde Adiş adı altında 16 hanede 34 Müslüman bulunmaktadır ${ }^{14}$. Bu Müslümanların Aşağı Adiş'ta mı yoksa Yukarı Adiş köyünde mi yaşadıkları belirtilmemiştir. 1846 tarihli Çüngüş Kefalet Defteri'ndeki verilere göre Adiş köyünde kefalet kapsamındaki Müslüman sayısı 26 kişidir $^{15}$. Bilindiği üzere kefalet defterlerinde kadınlar ile kefalet şartlarını taşımayan, diğer bir ifade ile akıl baliğ olmayan erkekler sayılmamaktadır. Adiş köyüne yerleşen Müslümanların Hindibaba ve Hoya köyünden geldikleri düşünülmektedir. Nitekim Adiş köyünden Öğretmen Fatih Arslan ile yapmış olduğumuz görüşmede, halihazırda ailesinin Adiş köyünde oturmakla birlikte dedesinin aslında Hindibaba köyünden Adiş'e geldiğini ifade etmiştir. Fatih Arslan, özellikle Ötegeçe (Gerger) tarafından Adiş köyüne yapılan eşkıyalık ve saldırıların önlenmesi için Adiş'teki Ermenilerin, dedesini kendilerini koruması için, Adiş’te oturmaya ikna ettiğini ilave etmiştir.

Bu kayıtlardan anlaşıldığı üzere XVI. yüzyılda tamamen bir Ermeni köyü olan Adiş'a zaman içerisinde bazı Müslüman ailelerin yerleştiği anlaşılmaktadır. Nitekim 1850 tarihli bir belgede Adış köyündeki iki Müslüman arasındaki bir alacak verecek ihtilafına değinilmiştir. 28 Haziran 1850 tarihli bir belgeye göre Çüngüş kazasına tabi Adiş köyü ahalisinden Salih yine aynı köyün sakinlerinden Ömer'den alacağı olan yirmi bin kuruşu defalarca istemesine rağmen Ömer adlı kişi borcunu ödemeye yanaşmamış hatta vilayetten savuşmuştur. Bunun üzerine Ömer'e kefil olan Mehmet ve Hüseyin'den bu miktar talep edildiğinde onlar da "bugün yarın diyerek" borcu ödememişlerdir. Bu nedenle Ömer'den veya kefili olan kişilerden bunun tahsili talep edilmiştir ${ }^{16}$. 1879 yılında Çüngüş'e gelen Ermeni Piskopos Karekin Vartabet Sırvantsdyants'e göre Adiş 300 haneli bir köydür. Köyde 100 talebeli bir okul bulunmaktadır. Ermenilerinin çoğu İstanbul'a gurbete gitmekte ve çoğunlukla fırıncılık yapmaktadırlar ${ }^{17}$.

\footnotetext{
${ }^{14}$ BOA, NFS.d., 2662.

${ }^{15} B O A$, NFS.d., 2663.

${ }^{16} B O A, A$.) AMKT. UM, 20/51, s.1.

17 Vahan Bardizaktsi-Boğos Natanyan-Karekin Vartabet Sırvantsdyants, Palu-Harput 1878, Yayına Haz: Arsen Yarman, Çevirenler: Sirvart Malhasyan-Arsen Yarman, Belge Yayınları, İstanbul, 2015, Cilt: 2, s. 521.
}

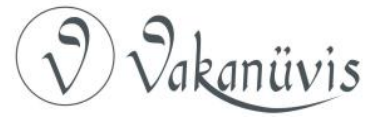


Muhtemelen XIX. yüzyılın başına kadar sadece Ermenilerin yaşadığı Adiş köyündeki Ermeniler, Gregoryan, Katolik ve Protestan cemaatlerine mensuptu. Bu nedenle kadim bir geçmişe sahip olan Adiş köyünden günümüze kalan yapılardan en önemlisi Surp Garabed Kilisesi'dir. Bununla birlikte günümüzde Adiş köyünde Ermeni mimari tarzı ile yapılmış taş duvarlı evler harabe haldedir. Köyde üç katlı Surp Garabed Kilisesi yaklaşık bir asırdır bakımsız olmasına rağmen halen daha varlığını sürdürmektedir. Surp Garabed Kilisesi, Fırat Nehri'nin oluşturduğu derin vadinin hemen kenarında bulunmaktadır. 1879 yılında Çüngüş'e gelen Karekin Vartabet Sırvantsdyants, Adiş köyünde Surp Garabed Kilisesi olduğunu, kilisenin İstanbul Hasköy'de bir dükkânı ve köyde de bir değirmeni olduğunu dile getirmektedir. Manastırın mallarının Harutyun Bığdoynets adına kayıtlı olduğunu, ayrıca harap halde bir kilisenin daha bulunduğunu ilave etmektedir ${ }^{18}$.

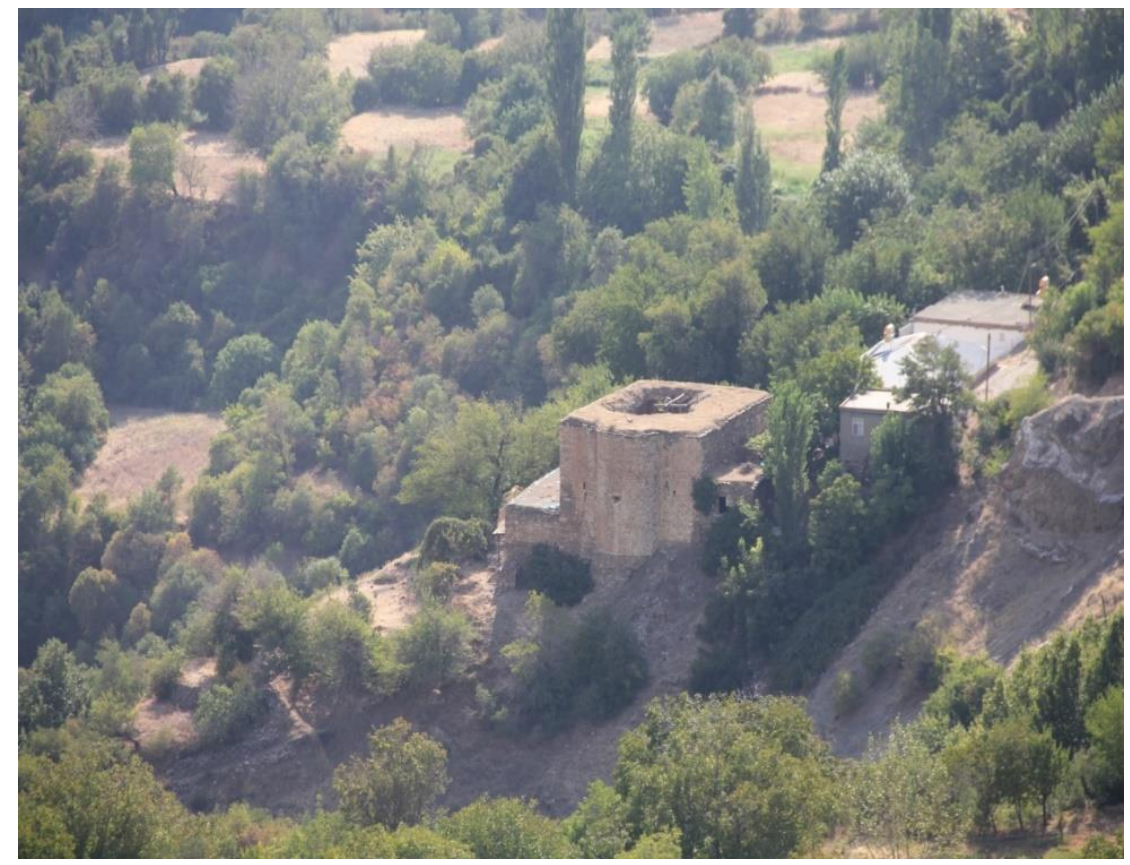

(Surp Garabed Kilisesi)

${ }^{18}$ Bardizaktsi-Natanyan-Sırvantsdyants, a.g.e, s. 521.

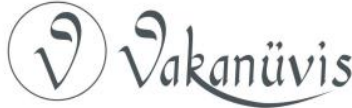


Kilise örtü sistemine kadar devam eden oldukça yüksek duvarlara sahipken özel mülkiyete verilmiş, iç kısmına üç ayrı katlı bir ev inşa edilmiştir. Ancak günümüzde ev terk edilmiş durumdadır. Kilisenin örtü sisteminin bir bölümü yıkılmıştır. Kiliseye ait herhangi bir kitabeye rastlanmamıştır. Bölgedeki diğer kiliselerden ayrı plan ve cephe özelliklerini yansıtmasına karşın apsisin dışa taşkın olması ve doğu cephesinin özenli bir şekilde kesme taş malzeme ile kaplanması bu yapıyı apsisi düz kiliselerden daha geç bir tarihe XVI. yüzyıla yakın tarihlenmesine neden olmaktadır. Kilise, doğu-batı doğrultusunda kareye yakın dikdörtgen, üç nefli bazilikal planlıdır. Yapının kuzey doğusunda bir şapeli bulunmaktadır. Kilise, Diyarbakır Kültür ve Tabiat Varlıklarını Koruma Bölge Kurulu'nun 15.12.2010 tarih 3596 sayılı kararı ile tescillenmiştir ${ }^{19}$.

1891 yılında Çüngüş'e gelen Arifi Paşa'nın seyahatnamesinde Adiş köyüne dair önemli veriler yer almaktadır. Arifi Paşa 7 Mayıs 1891 günü bir süre kaldığı Çermik'ten Çüngüş'e gelmiş ve yaklaşık iki hafta Çüngüş'te bulunmuştur. Arifi Paşa, Çüngüş'te kaldığı sırada Adiş köyüne de gitmiştir. Çüngüş'e bağlı köylerden sadece Adiş köyünü ziyaret ettiği anlaşılan Arifi Paşa, Adiş köyüne yaptığı seyahat ve izlenimleri hakkında özetle şunları aktarmaktadır:

10 Mayıs 1891 Pazar günü Adiş adındaki batı tarafındaki köye doğru hareket edildi. Bir buçuk saatte oraya varıldı. Adiş köyü bostanlı mamur bir köydür. 200 hanedir. Mükemmel bir kilisesi ve bir mektebi vardır. Maden Sancă̆ı'nda bu güzellikte bir köy görmedim. Yeşillik ve berrak sular içerisinde kuşların ötüşü insanın ruhunu okşamaktadır. Bu köydeki kadınlar başka yerde bulunmaz. Oradan yarım saat aşağıda Fırat nehrine gittik. Balık avı yaptık. Fırat nehrinin buradaki akışı pek dehşetlidir. Köye geri döndük. Ava giden Kürtlerin iki yaşında avladığı bir geyiği afiyetle yedik. Bu köyün arazisi hiç hükmünde olduğundan ahalisi gurbete gitmeği tercih etmektedir. 12 Mayıs 1891 günü Çüngüş'e geri döndük ${ }^{20}$.

Çüngüş Ermenileri, Gregoryan, Katolik ve Protestan olmak üzere üç mezhebe mensupturlar. Adiş köyündeki Ermenilerin de bu üç mezhebe

${ }^{19}$ Erbil Cömertler Aktuğ-İrfan Yıldız, Çüngüş’teki Kültür Varlıkları, Litera Türk Yayınları, Konya, 2019, s. 78.

20 Öztürk-Yılmazçelik, a.g.m, s. 107-108.

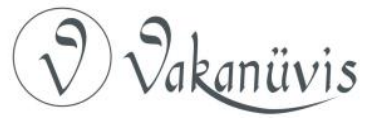


tabi oldukları görülmektedir. Ancak Gregoryan mezhebine mensup olanlar nüfusun büyük bir kısmını oluşturmaktadır. Bazı kayıtlarda 300, bazılarında ise 200 hane olarak geçen Adiş köyündeki Ermenilerin XIX. yüzyılın sonlarından itibaren yaşanan siyasi ve toplumsal hadiseler nedeniyle gittikçe başka şehirlere ve ülke dışına gittiği kayıtlardan anlaşılmaktadır. 1915 tarihli İskân Kanunu kapsamında Adiş köyündeki Ermenilerin de tamamının tehcire tabi tutulduğu anlaşılmaktadır. Cumhuriyet döneminde Adiş köyünün ismi değiştirilmiştir. Nitekim İçişleri Bakanlığı iller İdaresi Genel Müdürlüğü’nün 1 Mart 1968 tarihi itibarı ile hazırladığı "Köylerimiz" adlı eserde Adiş'in yeni adı Değirmensuyu olarak verilmiştir ${ }^{21}$.

\section{Ahalinin ve Köyün Ekonomik Durumu}

Adiş köyü, Fırat nehrinin kenarında engebeli bir arazide kurulmuştur. Sakinlerinin ihtiyaçlarını karşılayabilecek bir arazi potansiyeline sahip değildir. Buna rağmen Adiş-ı Ulyâ'nın vergi hasılatı 1518'de 7.529; 1530 'da 4.055, 1566 'da ise 16.954 kuruştur. Adiş-i Süflâ'nın vergi hasılatı ise $1518^{\prime}$ de $5.026,1530^{\prime}$ da $3.764,1566^{\prime}$ da $14.001^{\prime} \mathrm{dir}^{22}$. Tahsil edilen hasılat açısından bakıldığında Adiş köyü Aşağı ve Yukarı Adiş olarak dikkate alındığında, Çüngüş'e bağlı Müslüman köylerine oranla birinci sırada, ayrı ayrı dikkate alındığında ise Ermiye (Ermene), Elyos ve Kavak köylerinden sonra dördüncü sıradadır ${ }^{23}$.

Diyarbekir Beylerbeyliğine ait 106 numaralı 1566 tarihli Mufassal Tahrir Defterinin Ergani sancağı kısmında üretimle ilgili verilere yer verilmiştir. Bu dönemde Çüngüş nahiyesine bağlı olan Adiş köyünde aşağıdaki tarım ürünleri yetişmektedir ${ }^{24}$.

\footnotetext{
${ }^{21}$ Köylerimiz, Ankara, Başbakanlık Basımevi DSi, 1968.

22 Mehmet Salih Erpolat, “XVI. Yüzyılda Ergani Sancağı’ndaki Gayrimüslim İskân Yerleri ile Şahıs İsimleri Hakkında Bir Değerlendirme", Sosyal Bilimler Araştırma Dergisi, Yıl: 2, Sayı: 4, Diyarbakır, 2004, s.167.

${ }^{23}$ Ahmet Gündüz, 1523 M. (929 H.) Tarih ve 998 Nolu Tapu-Tahrir Defterlerine Göre Musul, Mardin, Çermik, Harput ve Çemişgezek Sancaklarının Mukayeseli Tahlili, Fırat Üniversitesi, Sosyal Bilimler Enstitüsü, Elazığ, 1993, Basılmamış Yüksek Lisans Tezi, s. 104.

24 Mehmet Salih Erpolat, "1566 Tarihli Mufassal Tahrir Defterine Göre Ergani Sancağı'nda Tarım ve Üretim", Tüm Yönleriyle Ergani illçesi ve Turizm, Editörler: Cihat Güzel\& Kenan Haspolat, Amaç Matbaacılık, İstanbul, 2014, s. 374.
}

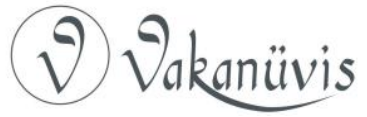




\begin{tabular}{|c|c|c|c|c|c|c|c|c|}
\hline : & 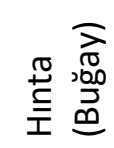 & 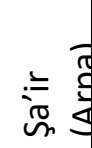 & 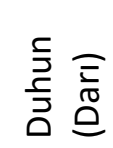 & 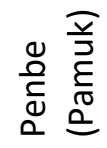 & 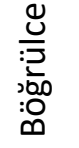 & 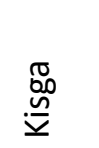 & 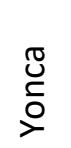 & 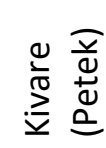 \\
\hline $\begin{array}{l}\text { Adiş-i } \\
\text { Ulyâ }\end{array}$ & 360 & 120 & 800 & 1200 & 600 & 1200 & 50 & 400 \\
\hline $\begin{array}{l}\text { Adiş-i } \\
\text { Süflâ }\end{array}$ & 600 & - & 1080 & 1350 & 192 & 1072 & 339 & 400 \\
\hline
\end{tabular}

Görüldüğü üzere Adiş köylerinde buğday, arpa, darı, pamuk, kisga, yonca ile bal üretimi yapılmaktadır. Bunun yanı sıra köyde yetiştirilen sebze-meyveler ise şunlardır:

\begin{tabular}{|l|l|l|l|l|l|l|}
\hline Köy & $\begin{array}{l}\text { Bağat } \\
\text { (Bağlar) }\end{array}$ & $\begin{array}{l}\text { Piyâz } \\
\text { (Soğan) }\end{array}$ & Bostan & Ceviz & $\begin{array}{l}\text { Anar } \\
\text { (Nar) }\end{array}$ & Meyve \\
\hline $\begin{array}{l}\text { Adiş-i } \\
\text { Ulyâ }\end{array}$ & 2300 & 200 & 100 & 50 & 700 & 1000 \\
\hline $\begin{array}{l}\text { Adiş-i } \\
\text { Süflâ }\end{array}$ & 2000 & 1000 & 480 & - & 450 & 320 \\
\hline
\end{tabular}

1566 tarihli tahrir kayıtlarına göre Adiş köylerinin her birinde 2 tane toplamda ise 4 adet değirmen vardır. Bu değirmenlerin her biri için 15 kuruş yıllık vergi alınmaktadır ${ }^{25}$.

1842 tarihli Çüngüş Nüfus Defterine bakıldığında Adiş köyünde birçok meslek erbabının bulunduğu anlaşılmaktadır. Söz konusu deftere göre Adiş köyü ahalisinin meslek ve meşguliyetleri şöyledir:

\begin{tabular}{|l|l|}
\hline Meslek ve Uğraşlar & Kişi Sayısı \\
\hline Köşger/Kefşger & 10 \\
\hline
\end{tabular}

25 Erpolat, "1566 Tarihli Mufassal Tahrir Defterine Göre Ergani Sancağı'nda Tarım ve Üretim”, s. 371-372.

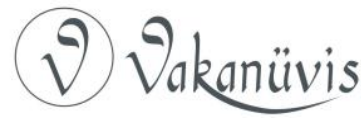




\begin{tabular}{|l|l|}
\hline Cülha/Cullah & 16 \\
\hline Babuşçu & 3 \\
\hline Katırcı & 18 \\
\hline Demirci & 2 \\
\hline Etmekçi/Ekmekçi & 5 \\
\hline Değirmenci & 1 \\
\hline Haddad & 18 \\
\hline Tarakçı & 1 \\
\hline Rencber & 31 \\
\hline Palancı & 4 \\
\hline Sabuncu & 1 \\
\hline Zurnacı & 1 \\
\hline
\end{tabular}

Rencberliği de dikkate aldığımızda Adış köyünde toplamda 93 kişinin bir meslek veya meşguliyet sahibi olduğu görülmektedir. Adiş büyük bir köy olmasına rağmen tarım alanları yetersiz olduğundan rencberlik işi ile uğraşan kişi sayısı çok azdır. Adiş ile ilgili belgelerde bu durum açıkça dile getirilmektedir. Bu nedenle köyün erkeklerinin önemli bir kısmı ailesini geçindirmek ve ihtiyaçlarını temin etmek amacıyla başka şehirlere çalışmaya gitmektedir. 1842 tarihli nüfus verilerine göre Adiş köyü Ermenilerinin en fazla gittiği yer İstanbul'dur. Bir köyden 174 kişinin geçimini temin etmek için Diyarbakır'a çok uzak bir yer olan İstanbul'a gitmesi mecburiyetin göstergesidir. Nitekim 1878 tarihinde Ermeni din adamlarının beyanlarına göre Adiş köyü Ermenilerinin çoğu İstanbul'a gurbete gitmekte ve çoğunlukla da fırıncılık yapmaktadır ${ }^{26}$.

Rencberlikten sonra en fazla icra edilen meslek demirciliktir. Demirci ve haddad aynı anlama gelen farklı ifadelerdir. 18 kişi katırcılık yapmaktadır. Katırcılık, malzeme ve yük taşımacılığı demektir. Cullah ve köşgerlik de önemli bir uğraş alanıdır. Farsça "ören, dokuyan" anlamındaki cûlâh veya cullâh kelimesi, Türkler arasında yaygın olarak çulha şeklinde de söylenir. Bu adlandırmayla Osmanlılar'da genellikle pamuklu dokuyan dokumacılar kastedilmiştir. Cullâhlık, hemen her Osmanlı şehir ve kasabasının temel iktisadî faaliyetini oluşturan zanaat kollarının en önde gelenlerinden biri olarak dikkati

${ }^{26}$ Bardizaktsi-Natanyan-Sırvantsdyants, a.g.e, s. 521.

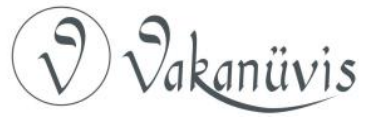


çeker ${ }^{27}$. Köşger/Kefşger ise Farsça ayakkabıcı, ayakkabı tamircisi demektir. Babuşcu tabiri de ayakkabıcı demektir. Köşger/kefşger ile babuşcu aynı anlamdadır. Palancı diğer bir ifade ile semercilik mesleğini icra eden 4 kişi bulunmaktadır. Ekmek pişirme işi ile uğraşan beş kişi vardır. Muhtemelen bu işi yapanlar başka yerlerde mesleklerini icra etmektedir. Zira köyde ekmek pişirme/fırın mesleği çok yaygın bir durum değildir. Herkesin bu ihtiyacını temin edebilecek güce ve imkâna sahip olduğu düşünülmektedir. Bununla birlikte sabun yapımı işini de bir kişinin yaptığı görülmektedir.

1842 tarihli nüfus defteri esas alındığında Çüngüş köylerindeki ahalinin sadece rencber ve çiftçilik ile uğraştığı görülmektedir. Bunun dışında başka bir meşguliyet ve meslek sahibi olunmadığı anlaşılmaktadır. Adiş Müslümanlarından 11 kişi rencberlik, bunun dışında ayrıca iki kişinin ise katırcılık yaptığı tespit edilmiştir. Yukarıda da ifade edildiği üzere Adiş köyünün yeterli araziye sahip olmaması nedeniyle Ermenilerin önemli bir kısmının başka şehirlere çalışmak için gittiği görülmektedir. Çüngüş ve bağlı köyler ahalisinin en fazla gittiği yerlerin başında i̇stanbul gelmektedir. Defterde "Asitane" olarak belirtilen İstanbul'a çoğunluğu Ermeniler olmak üzere çalışmak için gitmiştir. Çüngüş köylerinden en fazla gidilen yer İstanbul, ikinci yer Burs, üçüncü yer ise Adana'dır. Kasaba merkezindeki Ermenilerde bu oran \% 4 civarındadır. Çüngüş kasabasındaki Müslümanlarda bu oran \% 9, Müslüman köylerdeki nüfusun \% 11'inin bu üç şehre gittiği görülmektedir. Ancak bu oran Adiş köyünde yaklaşık \% 31 dolayındadır. Bu durum Adiş köyündeki erkeklerden üç kişiden birisinin İstanbul'a gittiği anlamına gelmektedir. Adiş köyünde çok sayıda kişinin İstanbul'da olması, Çüngüş'e telgraf çekilmesi yönündeki bir girişime Adiş Ermenilerinin büyük bir destek vermesine neden olmuştur.

Posta Telgraf Nezareti'nin 1894 tarihli bir yazısında; Maden Sancağı dahilindeki Ergani kasabasından Çermik'e ve oradan Çüngüş'e kadar bir telgraf hattının çekilmesi lüzumu dile getirilmiştir. Bunun için alt üst dörder odalı iki adet telgrafhane inşa edilecek, gerekli olan direklerin dikilmesi gerekecekti. Bu konuda mühendisler tarafından tanzim edilen harita ve keşifnameye göre Ergani'den elli kilometre mesafede olan Çermik'e ve oradan yirmi beş kilometre mesafede bulunan Çüngüş'e

${ }^{27}$ Feridun Emecen, “Cullâh”, DiA, İstanbul, 1993, Cilt: VIII, s.83-84.

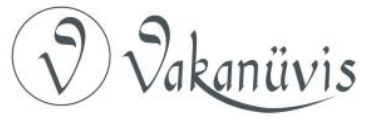


kadar çekilecek olan telgraf hattı için Avrupa'dan gerekli alet ve edavat getirilecekti. Telgraf alet ve edevatıyla kurulma ve saire masrafı olarak 6.027 frank 17 santimle 64.247 kuruş ve hattın senelik tamir ve tahkimi masrafıyla maaş ve sair masraflar 487 frank ile 33.800 kuruşa intiyaç vardır. Bunun yanı sıra getirilecek malzemelerin nakliye masrafı ve çalışacak kişilerin maaş ve diğer masrafları için ilave kaynak ayrılması gerekmektedir $^{28}$. Çermik'te bulunan Liva Tahrirat Müdürü Yusuf Vehbi Efendi'nin başkanlığında oluşturulan komisyonunun çalışmaları neticesinde 28.000 kuruş yardım toplanmıştır. Bu kapsamda Adiş köyünden yardım yapan kişiler ve yardım miktarları şöyledir:

\begin{tabular}{|l|l|}
\hline Yardım Yapan Kişi & Yardım Miktarı \\
\hline Oseb oğlu Mardiros & 250 \\
\hline Prus oğlu Mardiros & 150 \\
\hline Keşiş oğlu Bedros & 150 \\
\hline Ebkarman Avedik & 150 \\
\hline Hudegil Serkis & 150 \\
\hline Topal Mardiros & 150 \\
\hline Azer oğlu Epo & 150 \\
\hline Demirci Ovakim & 150 \\
\hline Pedermahi Haçır & 150 \\
\hline Giragos oğlu Ohannes & 150 \\
\hline Giragos oğlu Giragos & 120 \\
\hline Lisa Ohannes & 80 \\
\hline Bedros Keşiş oğlu Muhsi Haço & 60 \\
\hline Kaya Mahsi Artin & 80 \\
\hline Kiver Keşiş & 60 \\
\hline Toplam & 2.000 \\
\hline
\end{tabular}

Çüngüş'e telgraf çekilmesi teşebbüsü nedeniyle 1894 yılında Çüngüş ve köylerinden toplanan yardımlara bakıldığı zaman en fazla yardımın Adiş köyünde yapıldığı görülmektedir. 14 kişi tarafından 2.000 kuruş yardım yapılmıştır. Şehir merkezi ve köylerden yapılan yardımın yaklaşık

${ }^{28} B O A, D H . M K T, 288 / 14$, s. 11.

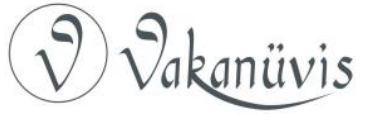


\% 13'üne tekabül etmektedir. Adiş köyündeki yardımların tamamı Ermeniler tarafından yapılmıştır. Bu durum Adiş köyü ahalisinin ekonomik olarak daha varlıklı olmasıyla ilgili olabileceği gibi erkeklerin neredeyse yarısının İstanbul'da bulunmasıyla da alakalıdır. Zira telgrafın çekilmesi halinde gurbetteki kişiler aileleri ile haberleşebilecek veya aileler maruz kaldığı sıkıntıları İstanbul'a iletebilecekti.

\section{Müslümanlarla Ermenilerin Münasebetleri}

Çüngüş'te Müslümanlarla Ermeniler asırlarca bir arada yaşamışlardır. Ermenilerle Müslümanlar arasındaki münasebetlere dair belgeler genellikle XIX. yüzyılın ikinci yarısında yoğunlaşmaktadır. Ermenilerin veya Ermeni din adamlarının tutumuna veya Müslümanlar ile devletin onlara karşı tutumuna dair belgelerden hareketle iki toplum arasındaki münasebetleri takip etmek mümkündür. Bununla birlikte Ermeniler arasında meydana gelen sıkıntılara dair belgeler de bulunmaktadır. Ermenilerin kendi aralarında meydana gelen husumetlerin bir kısmı kayıtlara yansımıştır.

Ermeni Patrikhanesi'nin 1 Kasım 1852 tarihli yazısında; Çüngüş kazası ile Adiş köyünde Ermenilere karşı kötü davranıldığı iddia edilmiştir. Yazıda, Ermeni reayasından bazı kişiler ile papazlardan birisine bazı iftiralar atıldığı ve bunlara kötü muamele yapıldığı belirtilmiştir. Sağlıklı bir yargılama yapılmadığı, bazılarının hapsedildiği ayrıca haksız vergi alındığı gibi birçok iddianın yer aldığı bir suçlama yapılmıştır ${ }^{29}$. Ancak bu yazıda haksızlığa uğrayan din adamları ve görevini kötüye kullandığı iddia edilen yetkililer hakkında bilgi verilmemiştir. 4 Temmuz 1853 tarihli bir belgede Hacı Avadis adlı bir kişinin arzuhalinde Çüngüş kazası köylerinden Adiş köyü sakinlerinden Bağbanlı Kürd adlı kişinin sekiz senelik mutasarrıf olduğu bir adet katırı cebren zapt ettiği belirtilmiştir. Hacı Avadis, haksız olarak gasp edilen hayvanının kendisine verilmesini istemiştir ${ }^{30}$.

Adiş köyü sakinlerinin 1856 yılında, Fırat'ın hemen ötesinde bulunan Gerger'e bağıı köylerden (Ötegeçe) gelen bazı eşkıyaların saldırılarına maruz kaldığı anlaşıımaktadır. Nitekim Çüngüş kazası ahalisinden olup, İstanbul'da bulunan Veliyüddin, Hacı Yarim vesairenin 4 Aralık 1856

${ }^{29} B O A, M V L, 258 / 80$.

${ }^{30} B O A$, A.) MKT. DV, 74/3, s.2.

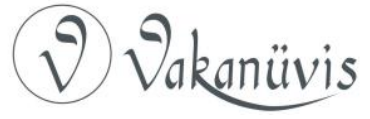


tarihli şikâyet arzuhalinde Gerger eşkıyasının saldırılarından yakınılmıştır. Söz konusu arzuhalde, Harput Sancağı'na bağlı Çüngüş kazası ahalisinden olup Gerger tarafından gelen Liyül, Osman Ağa, kardeşi İbrahim Ağa, Zengür Çirkin Ağa, Mahmud Ağa ve Tamburman Hasan'ın oğlu Osman Ağa ile Hoyalı Süleyman gibi Kürtlerin gelerek mallarını gasp ettikleri dile getirilmiştir. Meydana gelen saldırılarda ahaliden Azar oğlu Serkiz, Keşiş Ebker ve kardeşi Karabet adlı kimselerin saldırılarda hayatını kaybettıği, ayrıca dört kişinin de yaralandığı belirtilmiştir. Bu şekilde insanları katleden ve mallarını yağmalayan Kürtlerin bu saldırılarının ilgili makamlara iletilmesine rağmen herhangi bir tedbir alınmadığı vurgulanmıştır. Sekiz aydan beri de bu eşkıyanın tasallutuna maruz kalındığı ve köylerin muhasara altında olduğu zikredilerek yetkililerin gerekli tedbirleri alması istenmiştir ${ }^{31}$.

Bu telgraftan hareketle eşkıyanın saldırısında her ne kadar bazı Ermeniler hayatını kaybetmiş ise de Müslümanların da bu saldırıların hedefinde olduğu görülmektedir. Nitekim şikâyeti yapanların Müslüman olduğu görülmektedir. Gerger kazasından Çüngüş ve köylerine yönelen eşkıyalık ve zulümlerin zaman zaman devam ettiği görülmektedir. Şerif Ağa'nın kaza müdürü olduğu dönemde Ötegeçe'den gelen eşkıyaların kaza ahalisinin hayvanlarını, mal ve eşyalarını sürekli gizli ve açık bir şekilde gasp ettikleri Çüngüş kazasında bulunan ulema, eşraf, ahali ve muhtarlar tarafından gönderilen şikâyet dilekçesinde dile getirilmiştir ${ }^{32}$.

Bu dönemde Çüngüş'e bağlı Hoya köyüne yapılan eşkıyalık hareketlerinin Adiş köyü Ermenilerini de tedirgin ettiği kayıtlara yansımıştır. Vaziyet, Ermeni ahalisi ve din adamlarının şikâyeti üzerine konu Ermeni Patrikhanesi yoluyla Sadaret'e iletilmiştir. Adiş köyü Ermenilerinin Patrikhaneye gönderdiği bir şikâyet telgrafına göre; Harput Eyaletine bağlı Çüngüş kazası havalisinde bulunan "taife-i Ekrad sergerdeleri", yüz haneden ibaret olan Hoya adlı köyü yakmak, insanları katletmek ve malları yağmalamak gibi cürümlere kalkışmış hatta çocuklara varıncaya kadar onları telef etmiştir. Bundan dolayı tüm ahalinin emniyet ve huzuru bozulmuştur. Kürt eşkıyasının Hoya köyüne yaptığı saldırıların Adiş köyüne de sirayet edeceği, Adiş köyünü de "ihrak ve harap edileceği" kaygısı hasıl olmuştur. Kürtlerin bu şekilde zalimane

\footnotetext{
${ }^{31} B O A, M V L, 177 / 10$.

${ }^{32} B O A, M V L, 679 / 79$, s. 1.
}

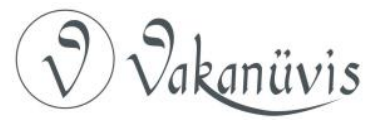


hareketleri herkesin emniyet ve istirahatlerini bozmuştur. Ermenice olarak kaleme alınan arzuhalde Kürt eşkıyasının kontrol altına alınması ve elebaşlarının cezalandırılması istenmiştir. Ayrıca gasp edilen malların geri alınması ve mağduriyetlerin telefi edilmesi istirham edilmiştir ${ }^{33}$. Konuya ilişkin belgede Çüngüş'ün Hoya köyüne saldıran ve "taife-i Ekrad" diye ifade edilen kişilerin hangi köy veya köylerden oldukları, isimleri ve Hoya köyünde mağdur olan kişilerin isimleri belirtilmemiştir. Halkı Müslümanlardan oluşan Hoya köyüne yapılan veya yapıldığı iddia edilen bir saldırının Adiş köyüne de yapılacağına dair vehim veya kaygı bu süreçte Adiş köyü Ermenilerinin Hoya köyü gibi bir saldırıya maruz kalmamak için tedbirli davranmasına veya daha önce yaşanmış benzer olaylara işaret etmektedir.

Bu süreçte bazı din adamlarının sorumsuz davranışları ve yersiz iddiaları iki toplum arasındaki ilişkilerin bozulmasına neden olmuştur. Zira din adamları, ruhani ve cismani konumları nedeniyle Ermeni toplumu üzerinde etkili olduğu gibi Osmanlı Devleti nezdinde de mensubu oldukları cemaatleri temsil etmekte idiler. Bu dönemde Adiş köyü Ermenilerinden Ohannes'in silahla yaralanması Ermeni din adamları tarafından istismar edilmeye çalışılmıştır. Çüngüş Ermeni Murahhas vekili Minas ${ }^{34 \prime} ı$ Ergani'den Ermeni Patrikhanesi'ne çektiği telgrafta sekiz gün önce Adişli Ohannes veled-i Bedros'un tüfekle ayaklarından yaralandığı ve ahalinin ziyadesiyle ıstırapta bulunduğu iddia edilerek gereğinin yapılmasını istemiştir ${ }^{35}$. Bunun üzerine iddialar Diyarbakır'dan sorulmuştur. Gerekli tahkikat yapılarak iddiaların mahiyeti araştırımıştır. Diyarbakır Valisi Sırrı Paşa tarafından konuya ilişkin Sadaret'e gönderilen 26 Eylül 1888 tarihli cevabî yazıda özetle şöyle denilmektedir.

Emirleriniz üzerine tahkikat memurları gönderdim. Tahkikat memuru şimdi döndü. Kendisinden aşağıdaki malumat alındı. 15 Eylül 1888 Pazartesi gecesi saat üç sıralarında köyün ortasında olan değirmen önünde atılan bir tüfekten çıkan saçma tanelerinin Adişli Ohannes'in

\footnotetext{
33 BOA, HR. MKT, 150/53, s.2.

341287 (1870-1871) tarihli Diyarbakır Vilayet Salnamesinde Çüngüş'te Rahip Minas Efendi'dir. Diyarbakır Salnameleri (1286-1323), Yayına Hazırlayan: Ahmet Zeki İzöer, Diyarbakır Büyükşehir Belediyesi Yayınları, İstanbul, 1999, C.ı, s. 127.

${ }^{35}$ BOA, Y. MTV, 35/60, s. 1; BOA, i. DH, 1099/86187.
}

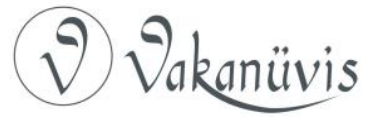


ayaklarına isabet ederek yaralandığı doğrudur. Fakat tüfeği atan kimdir, sebebi nedir? Bunlar malum değildir. Şimdiye kadar gerek yaralı Ohannes ve gerek Ermeni murahhası (piskopos) tarafından bu hususta mahalli yetkililere müracaat edilmemiştir. Bu nedenle Ohannes'i yaralayan kişi henüz ele geçmemiştir. Bununla birlikte söz konusu gün hem pazar olduğu hem de Adiş köyünde Ermenilerin etkinliği olması hasebiyle gündüz sevinç gösterisinde bulunulmuştur. Bu sırada pek çok tüfek atıldığı gibi gece tüfek atanların bunlardan biri olması ihtimali vardır. Adiş köyü üç yüz hane olup sakinleri tamamen Ermeni'dir. Gençlerin de hemen kaffesi İstanbul'dadır. Gerek İslam gerek Hıristiyan ahalinin rahatları yerindedir. Öyle murahhasın haber verdiği ıstıraptan eser yoktur. İşin hakikati bundan ibarettir.

Diyarbakır Valisi Sırrı Paşa, vaziyetin mahalli yetkililere iletilmeden İstanbul Ermeni Patrikhanesi'ne bildirilmesinin iyi niyetli bir tutum olmadığına dikkat çekmiştir. Sırrı Paşa, sakinleri tamamen kendi milletlerinden olan bir köyün ortasında atılan tüfekten yaralanan bir kişiden dolayı ahalinin ziyadesiyle ıstırapta olduğunun beyan edilmesini maksatlı bir ihanet olarak değerlendirmektedir. Ermeni Murahhas vekilinin işi başka bir renkte göstermeye çalışmasını Ermeni müfsitlerinin malum olan "amâl ve maksatlarına" hizmet etmek olarak yorumlamaktadır. Sırrı Paşa'ya göre Ermeni murahhas vekili bu tavrı ile Ermeni fesatçıların amacına hizmet etmektedir. En küçük bir hadisenin bağlamından koparılması, Ermenileri Batı kamuoyunda (nazar-ı ecânibde) mazlum göstermek fikrine dayanmaktadır. Gazetelere bile yansıyan bu haber nedeniyle sorumsuzca davranan Ermeni din adamlarından izahat istenmesi gerektiği telgrafın sonunda dile getirilmiştir ${ }^{36}$.

\section{Ermeni Olayları}

Ermeni sorununun ortaya çıkmasında Batılı güçlerin tahrikleri ve teşvikleri olduğu gibi, Fransız İhtilali'nin, Ermeni Kilisesi ve Patrikhanesinin, Ermeni komitalarının, misyoner faaliyetlerin etkisi de yadsınamaz. Şark meselesi ve emperyalizmin temellendirdiği Ermeni sorunu Türkler ile Ermenler arasında bitmeyen/ bitmeyecek düşmanlık tohumlarını ekmiştir. Fransa, XVI. yüzyıldan itibaren Ermeniler ile

${ }^{36} B O A, Y . M T V, 35 / 60$, s. 2.

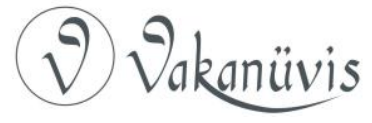


ilgilenmeye ve İmparatorluk sınırları içinde kendisine bağlı Katolik Ermeni cemaati oluşturmaya çalışmıştır ${ }^{37}$. Fransa'yı daha sonra İngiltere ve Rusya takip etmiştir. Her iki devlette aynı yöntemi kullanarak Ortodoks ve Protestan Ermeni cemaati oluşturmaya ve Ermenileri kendi siyasi ve iktisadi emelleri doğrultusunda balmumu gibi şekillendirmeye gayret etmiştir ${ }^{38}$.

Osmanlı Devleti idaresinde binlerce yıl Müslümanlarla bir arada yaşayan ve "teba-i sadıka" olarak vasıflandırılan Ermeniler, Ermeni komitelerinin örgütlenmesi sonrasında Müslümanlarla ve devlet olan bağlarını koparmaya başladı. 1877-1878 Osmanlı-Rus Harbi sonrasında gittikçe ayrılıkçı siyaset takip eden Ermeniler birçok yerde isyan ettiler. Bu isyanların özellikle 1895 yılında yoğunlaştığı ve adeta topyekûn bir başkaldırı halini aldığı görülmektedir ${ }^{39}$. Bu kapsamda 1 Kasım 1895 Cuma günü Diyarbakır vilayet merkezinde de çok sayıda camiye saldırı yapıldı. Bu saldırılar neticesinde Ermeniler ile Müslümanlar arasında kanlı bir boğuşma yaşandı. Vilayet merkezinde üç gün, vilayet genelinde ise yaklaşık on beş gün süren olaylarda her iki taraftan da çok sayıda insan hayatını kaybetmiş, yaralanmış ve ekonomik yapı büyük ölçüde sarsılmıştır. Vilayet merkezinde başlayan olaylar kısa süre içerisinde dalga dalga sancak, kaza, nahiye ve köylere de sirayet etmiştir. Bu kapsamda Çüngüş nahiyesinde de birtakım sıkıntıların yaşandığı anlaşılmaktadır. Nitekim Diyarbakır Valisi Enis Bey'in 9 Kasım 1895 tarihinde Dâhiliye Nezaretine gönderdiği bir telgrafta, Çermik kasabasında meydana gelen heyecanın alınan tedbirlerle teskin edildiği, şimdi de Çüngüş kasabasında toplanan Kürtlerin defedilmesine çalışıldığı bildirilmiştir ${ }^{40}$.

37 Dündar Aydın, "Ermeni Meselesinin Ortaya Çımasında Fransa'nın Rolü”, Tarih Boyunca Türklerin Ermeni Toplumu ile Iilişkileri Sempozyumu (8-12 Ekim1984), Ankara, 1985, s. 285-287.

38 Bilal Şimşir, "Ermeni Propagandasının Amerika Boyutu Üzerine", Tarih Boyunca Türklerin Ermeni Toplumu ile ilişskileri Sempozyumu (12 Ekim 1984), Erzurum Atatürk Üniversitesi Yayınları, Ankara, 1995, s. 90-95.

${ }^{39}$ Ermeni isyanları hakkında ayrıntılı bilgi için bkz. Mehmed Hocaoğlu, Tarihte Ermeni Mezalimi ve Ermeniler, Anda Dağıtım, İstanbul, 1976, s. 180 vd; Azmi Süslü, Ermeniler ve 1915 Tehcir Olayı, Yüzüncü Yıl Üniversitesi Yayınları, Ankara, 1990, s. 58-59.

${ }^{40} B O A, D H$. ŞFR, 183/111, s.1.

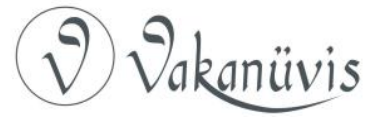


Çüngüş'te meydana gelen 1895 olaylarıyla ilgili arşiv belgeleri incelendiğinde olaylarla ilgili çok fazla bilginin yer almadığı görülmektedir. Olaylarda kaç kişinin hayatını kaybettiği, kaç kişinin yaralandığı, yağmaların boyutu, olaylara sebebiyet verenlerin kimliği hakkındaki sorular büyük ölçüde cevapsız kalmaktadır. Ermeni din adamlarının konuya ilişkin yazışmalarında da bu konuda somut bir bilgi mevcut değildir. Ancak bütün bunlara rağmen Çüngüş'te meydana gelen olaylarda bazı Ermenilerin mağdur olduğu tartışmasızdır. Bu durum Ermeni din adamlarının Ermeni Patrikhanesine çektiği telgraflarda dile getirilmiştir. 1895 olayları sırasında mağdur olan veya olduğu iddia edilen Ermenilerin ödemekle mükellef oldukları vergilerin ertelenmesi veya söz konusu vergilerin yeni bir düzenleye tabi tutularak ödenmesi söz konusu süreçte talep edilmiştir. Bu durumu dikkate alan yetkililer bazı kararlar alıp vilayetlere bildirmiştir. Ancak buna rağmen yeni düzenlemeye göre alınacak vergilerin oranı ve süresi hakkında gerek mevzuattaki boşluk ve gerekse de mahalli yetkililerin kötü niyeti nedeniyle bir takım şikâyet ve itirazlar meydana gelmiştir.

Bununla birlikte birtakım Ermenilerin 1895 yılında yaşanan bazı sıkıntıları ileri sürerek vergi vermeye yanaşmadığı, bunun için patrikhane, misyoner teşkilatları, konsolosluk ve sefaretler yoluyla mağduriyet edebiyatı yaptığı da bilinmektedir. Bu süreçte özellikle İstanbul'da bulunan Adişlilerin etkin rol oynadığı ve mağduriyetlerini Ermeni Patrikhanesine ve ilgili makamlara ilettiği anlaşılmaktadır. Zira daha öncede bahsedildiği üzere Adiş köyü yeterli araziye ve esaslı bir geçim kaynağına sahip olmadığı için çok sayıda kişi İstanbul'a çalışmak için gitmekte idi. 1895 olayları sonrasında bu kişilerin bir kısmı memleketlerine gönderilmiş ve geldikleri yerde iş imkânı bulunmadığından ekonomik sıkıntı yaşamaya başlamışlardır. Bu nedenle İstanbul'da güçlü bir "Adiş lobisi" olduğu ve bu kişilerin Çüngüş'te yaşanan veya yaşandığı iddia edilen hadiseleri Ermeni Patrikhanesi'ne ileterek iddiaların takipçisi olduğu söylenebilir.

1895 olayları sonrasında Çermik kazasıyla Çüngüş nahiyesi ve Adiş köyündeki Hristiyan ahalisinin, karışıklık esnasında zarar gördükleri halde damga ve emlak vergileri tahsili için kendilerine baskı yapıldığı yönünde iddialar bulunmaktadır. Çüngüş'teki Ermeni din adamları tarafından Ermeni Patrikhanesine yapılan başvurularda çiftçilerin

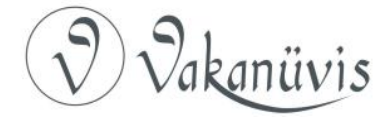


mağduriyetine vurgu yapılarak, bu kişilerden vergi alınmaması talep edilmiştir ${ }^{41}$. Ermeni Patrikhanesi, bu iddiaları Adliye ve Mezahip Nezareti'ne gönderdiği 17 Kasım 1897 ve 26 Aralık 1897 tarihli iki kıta yazı ile dile getirmiştir.

Bu yazılarda; Çüngüş nahiyesine bağlı Adiş köyü ahalisinin durumu ele alınmıştır. Buna göre Çüngüş nahiyesinin Adiş Köyü ahalisi "vaka-i malûmeden" dolayı zarara uğramış, aç ve çıplak bir vaziyette barakalar içinde kışın soğuğundan titremektedir. Bu kişiler yardıma muhtaç iken mahalli hükümet tarafından temettü ve emlak vergileri talep edilmekte ve hatta tehdit ve hapis gibi şiddetli muamelede bulunmaktadır. Halbuki ahalinin büyük bir kısmı İstanbul'dan memleketlerine gönderilmiş olduğundan dolayı icra ettikleri meslekleri orada bir işe yaramaz durumdadır. Zaten ihtiyaçlarını karşılamaya mahsus olan küçük bahçelerinden başka ziraata elverişli arazileri de bulunmamaktadır. Bu arada bu bahçelerden bir kısmı da harap ve viran haldedir. Yüksek bir dereceye varmış olan sefil ve perişan hallerine merhamet edilerek temettü ve emlak vergilerinin affedilmesi istirham edilmiştir. Adiş köyü ahalisinin maruz kaldığı durum Parikhane tarafından da bilindiği ve bu nedenle "şayan-ı merhamet bir halde bulunan" ahalinin ödemeye zorlandığı vurgulandıktan sonra vergilerden muaf olması yinelenmiştir ${ }^{42}$.

Bunun üzerine Dahiliye Nezareti, bu iddiaların tahkik edilerek, gereğinin yapılmasını Diyarbakır Valiliği'ne bildirmiştir. Bu arada temettü vergileri hakkındaki düzenlemenin Meclis-i Mahsusa-i Vükelâ tarafından ittihaz olduğuna ve irade-i seniye tarafından uygun görüldüğüne de dikkat çekilerek ona göre yetkililerin hareket etmesi istenmiştir ${ }^{43}$. Bunun üzerine Diyarbakır Vilayeti'nden Dahiliye Nezareti'ne gönderilen 15 Mart 1898 tarihli cevabî yazıda Ermeni Patrikhanesi'nin iddialarına değinilmiştir. Diyarbakır Valisi Halid Bey, yapılan uygulamaların mevzuata uygun bir şeklide icra edildiğini, iddia edildiği gibi herhangi bir kişinin tutuklanmadığını, kimseye baskı

\footnotetext{
${ }^{41}$ BOA, DH.TMIK.M.. , 43/34, s.2.

42 BOA, DH. TMIK. M, 43/34, s.5; BOA, DH. TMIK. $M, 46 / 23$, s. 3.

${ }^{43}$ BOA, DH. TMIK. M, 43/34, s.4; BOA, DH. TMIK. M, 48/52.
}

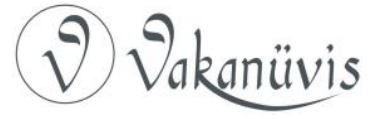


yapılmadığını, tüm bu iddiaların kırk elli kuruşluk vergiden kaçmak fikrine dayanıldığını dile getirmiştir ${ }^{44}$.

Bu konudaki iddiaların devam etmesi üzerine Diyarbakır Valisi Halid Bey ikinci bir yazı göndermiştir. 10 Mayıs 1898 tarihli yazıda, Çüngüş ve Adiş'taki Ermenilerden adalet ve hakkaniyet dairesinde ruhani reisler ve muhtarlar huzurunda tetkikat icra edilerek vergilerin herkesin ticaretlerine göre uygun görüldüğü belirtilmiştir. Bu yapılırken tahammülleri dışında görülen miktarlar indirilerek kimsenin mağduriyetine ve şikayetine meydan verilmemiştir. Bu uygulamadan dolayı Çüngüş nahiyesindeki Ermeni ruhaniler ve muhtarlar tarafından bir teşekkür evrakı da tanzim edilmiştir. Ermeni ruhanileri ve muhtarlarından yedi kişinin imzasının olduğu 17 Nisan 1898 tarihli teşekkür yazısında verginin hakkaniyetle alındığı, kimsenin mağdur edilmediği ve bu uygulamadan herkesin hoşnut kaldığı dile getirilmiştir. Ayrıca Ermenilerin ne kadar ödemesi gerekirken yapılan indirimlerle tazmin edilen vergi miktarı ayrıntılı bir şekilde çizelge halinde yazıya ilave edilmiştir ${ }^{45}$.

\section{Sonuç}

Çüngüş, Müslümanlar ve gayrimüslimlerin yaşadığı bir yerleşim merkezidir. 1516 yılında Osmanlı idaresine girdiğinde şehir merkezi nüfusunun büyük bir kısmını Ermeniler, geri kalanını ise Müslümanlar oluşturmakta idi. Bununla birlikte bu dönemde Çüngüş kazasına/nahiyesine bağı köylerden sadece Adiş'ta Ermeniler yaşamakta idi. Tahrir defterleri, cizye kayıtları, nüfus ve kefalet defteri ile arşiv belgeleri bunu teyit etmektedir. Adiş, kayıtların büyük bir kısmında Adiş-i Süflâ ve Adiş-i Ulyâ şeklinde geçmekle birlikte bir kısmında ise sadece Adiş olarak tanımlanmıştır. Çüngüş'ün batısında ve Fırat Nehri'nin kenarında engebeli bir alanda kurulan Adiş, Çüngüş'e bağlı Müslüman köylerine kıyasla önemli bir nüfusa sahiptir. Adiş, konumu itibarı ile geniş ve ihtiyacı karşılayacak bir araziye sahip değildir. Hemen önünden akan Fırat Nehri'nin etkisi Çüngüş ile Adıyaman'a bağlı Gerger'in doğal sınırını oluşturmaktadır. Fırat Nehri, bölgenin bitki örtüsü ve iklimi üzerinde olumlu bir etkiye sahiptir. XVI ve XVII. yüzyıl

\footnotetext{
${ }^{44}$ BOA, DH.TMIK.M.. , 52/53; BOA, DH. TMIK. M, 43/34, s.4.

${ }^{45}$ BOA, DH.TMIK.M.. , 53/35, s.4.
}

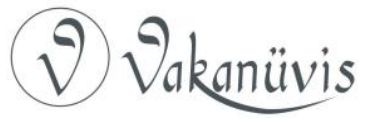


kayıtlarına göre Adiş köyünde sadece Ermeniler yaşarken XIX. yüzyılın başından itibaren Müslümanlar da Adiş köyüne yerleşmiştir. XIX. yüzyııın ikinci yarısından itibaren Fırat'ın öte yakasında Gerger'e bağlı yerleşim merkezlerinden, diğer bir ifade ile "Ötegeçe" olarak tanımlanan yerlerden Adiş köyüne bir takım eşkıyalık faaliyetlerinin yapıldığı görülmüştür. Bazen Müslüman köylere de yapılan bu eşkıyalık hareketlerini önlemek için gerekli tedbirler alınmıştır. Ancak Fırat Nehri'nin ötesindeki yerleşim merkezlerinin Adıyaman'a bağlı olması ve nehir nedeniyle eşkıya takibinin zorluğu bu suistimallerin zaman zamam devam etmesine neden olmuştur. Nitekim 1895 Ermeni olayları sırasında Gerger tarafından gelen eşkıya, Adiş köyüne saldırılarda bulunmuş ve birtakım mağduriyetler yaşanmıştır. Adiş köyü, yetersiz tarım alanlarına sahip olması nedeniyle köyün erkeklerinin önemli bir kısmı İstanbul'a giderek ailesinin ihtiyaçlarını temin etmeye çalışmıştır. Adiş köyünde Hıristiyanlığın Gregoryan, Katolik ve Protestanlık mezheplerine mensup kişiler bulunmaktadır. Birinci Dünya Savaşı esnasında Sevk ve İskân Kanunu kapsamında köydeki Ermeniler tehcire tabi tutulmuştur. XIX. yüzyılın sonunda eğitim kurumu ile birisi harabe iki kilisenin köyde olduğu görülmektedir. Bunlardan birisi olan Surp Garabed Kilisesi, halen daha varlığını muhafaza etmektedir. Ancak böylesine kadim bir yerleşim merkezinde bulunan bu kilisenin tamamen yok olmaması için yetkililerin ve ilgili makamların gerekli tedbirleri alması gerektiği kanaatindeyiz.

\section{Kaynakça}
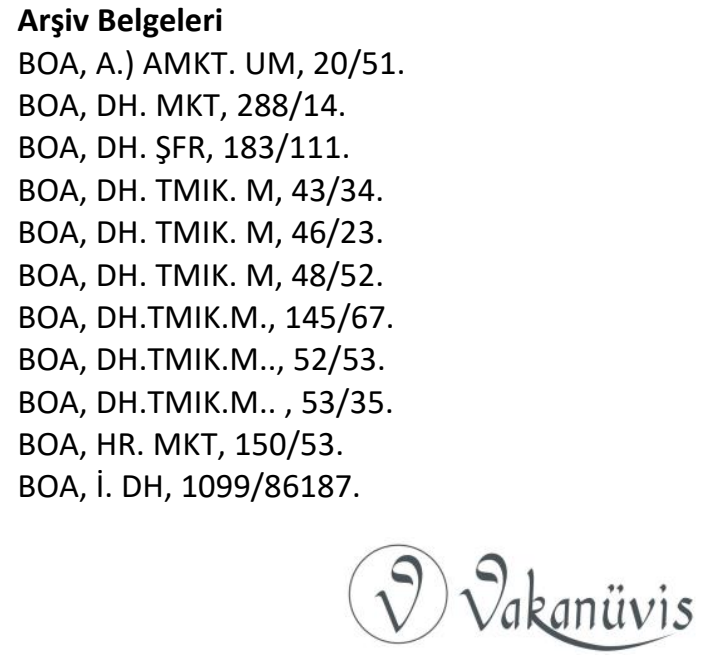


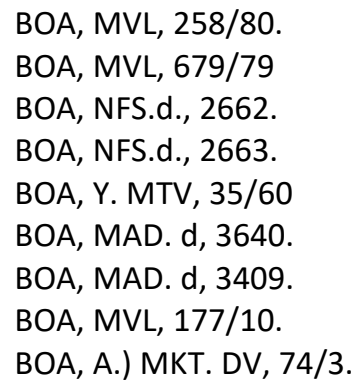

\section{Kitap, Makale ve Ansiklopedi Maddeleri}

Aktuğ, Erbil Cömertler-Yıldız, İrfan, Çüngüş'teki Kültür Varlıkları, Litera Türk Yayınları, Konya, 2019.

Aydın, Dündar, "Ermeni Meselesinin Ortaya Çımasında Fransa'nın Rolü", Tarih Boyunca Türklerin Ermeni Toplumu ile Ilişkileri Sempozyumu (8-12 Ekim1984), Ankara, 1985, s. 285-287.

Bardizaktsi, Vahan- Natanyan, Boğos-Sırvantsdyants, Karekin Vartabet, Palu-Harput 1878, Yayına Haz: Arsen Yarman, Çevirenler: Sirvart MalhasyanArsen Yarman, Belge Yayınları, İstanbul, 2015, Cilt: 2.

Bulduk, Abdülgani, El-Cezîre'nin Muhtasar Tarihi, Yay. Haz: Mustafa ÖztürkIbrahim Yılmazçelik, Fırat Üniversitesi Orta Doğu Araştırmaları Merkezi Yayınları, Elazığ, 2004.

Diyarbakır Salnameleri (1286-1323), Yayına Hazırlayan: Ahmet Zeki İzgöer, Diyarbakır Büyükşehir Belediyesi Yayınları, İstanbul, 1999, C.I.

Emecen, Feridun, "Cullâh", DiA, İstanbul, 1993, Cilt: VIII, s.83-84.

Erpolat, Mehmet Salih, "1566 Tarihli Mufassal Tahrir Defterine Göre Ergani Sancağı'nda Tarım ve Üretim”, Tüm Yönleriyle Ergani Ilçesi ve Turizm, Editörler: Cihat Güzel\& Kenan Haspolat, Amaç Matbaacılık, İstanbul, 2014.

Erpolat, Mehmet Salih, "XVI. Yüzyılda Ergani Sancağı'ndaki Gayrimüslim İskan Yerleri ile Şahıs İsimleri Hakkında Bir Değerlendirme", Sosyal Bilimler Araştırma Dergisi, Yıl: 2, Sayı: 4, Diyarbakır, 2004, s.176-178.

Feridun, Münşeatü's-Selatin, İstanbul, 1274, C.I.

Gündüz, Ahmet, 1523 M. (929 H.) Tarih ve 998 Nolu Tapu-Tahrir Defterlerine Göre Musul, Mardin, Çermik, Harput ve Çemişgezek Sancaklarının Mukayeseli Tahlili, Fırat Üniversitesi, Sosyal Bilimler Enstitüsü, Elazı̆̆, 1993, (Basılmamış Yüksek Lisans Tezi)

Hocaoğlu, Mehmed, Tarihte Ermeni Mezalimi ve Ermeniler, Anda Dağıtım, İstanbul, 1976.

İlhan, Mehdi, Amid (Diyarbakır) 1518 Tarihli Defter-i Mufassal, TTK, Ankara, 2000.

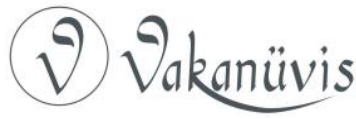


Kırzıoğlu, Fahrettin, "Çermik Kasabası Üzerine Notlar", Kara Amid Dergisi, S.1, ìstanbul, 1956.

Öztürk, Mustafa-Yılmazçelik, İbrahim, “Arifî Paşa'nın Seyahatnamesi Diyarbekir Seyahati", Belgeler, Türk Tarih Kurumu, Cilt: 18, Sayı: 22, Yıl: 1997.

Süslü, Azmi, Ermeniler ve 1915 Tehcir Olayı, Yüzüncü Yıl Üniversitesi Yayınları, Ankara, 1990.

Şimşir, Bilal, "Ermeni Propagandasının Amerika Boyutu Üzerine", Tarih Boyunca Türklerin Ermeni Toplumu ile ilişkileri Sempozyumu (12 Ekim 1984), Erzurum Atatürk Üniversitesi Yayınları, Ankara, 1995, s. 90-95.

Turan, Osman, Selçuklular Tarihi ve Türk-Islam Medeniyeti, Ötüken Yayınları, İstanbul, 1980. 